\title{
СИНХРОНИЗАЦИЯ ПЕРЕЧНЯ ДОКУМЕНТОВ, ПРЕДСТАВЛЯЕМЫХ В СОСТАВЕ ХОДАТАЙСТВ, КАК ОДИН ИЗ ВАРИАНТОВ СОВЕРШЕНСТВОВАНИЯ КОНТРОЛЯ ЗА ЭКОНОМИЧЕСКОЙ КОНЦЕНТРАЦИЕЙ И ИНОСТРАННЫМИ ИНВЕСТИЦИЯМИ
}

\section{SYNCHRONIZATION OF THE LIST \\ OF DOCUMENTS SUBMITTED AS PART \\ OF THE APPLICATIONS, AS ONE \\ OF THE OPTIONS FOR IMPROVING \\ CONTROL OVER ECONOMIC \\ CONCENTRATION AND FOREIGN \\ INVESTMENTS}

\section{Mazurenko}

Summary. The article analyzes the lists of documents submitted simultaneously with applications for consent to the implementation of transactions subject to control over economic concentration and foreign investments. The problematic aspects that impede the effective performance of the functions assigned to the antimonopoly authority were identified. According to the results of the study, it was established that in order to improve control over economic concentration and foreign investments, it is necessary to synchronize the provisions of Law № 135 and Law № 57 in terms of the documents submitted.

Keywords: competition, economic concentration, foreign investments, application, foreign investor, beneficial owner, controlling persons, strategic meaning, licenses.
$\mathbf{K}$ онтроль за экономической концентрацией и иностранными инвестициями - важнейшие направления деятельности антимонопольного органа, позволяющие как нивелировать риск причинения ущерба экономике, так и обеспечить оборону страны и безопасность государства.

Несмотря на различные цели осуществления указанных функций, процедуры осуществления контроля за экономической концентрацией и иностранными инвестициями тесно связаны между собой, в связи с чем ответственным федеральным органом исполнительной власти с целью минимизации издержек назначен антимонопольный орган.

Основания осуществления рассматриваемых видов контроля, в том числе перечни сделок (действий),

\author{
Мазуренко Владимир Андреевич \\ Аспирант, Московский государственный \\ юридический университет имени О.Е. Кутафина \\ (МГЮА) \\ mazurenko.vladimir96@mail.ru
}

Аннотация. В статье анализируются перечни документов, представляемых одновременно с ходатайствами о получении согласия на осуществление сделок, подлежащих контролю за экономической концентрацией и иностранными инвестициями. Выявлены проблемные аспекты, препятствующие эффективному исполнению возложенных на антимонопольный орган функций. По результатам исследования установлено, что в целях совершенствования контроля за экономической концентрацией и иностранными инвестициями необходима синхронизация положений Закона № 135 и Закона № 57 в части представляемых документов.

Ключевые слова: конкуренция, экономическая концентрация, иностранные инвестиции, ходатайство, иностранный инвестор, бенефициарный владелец, контролирующие лица, стратегическое значение, лицензии.

на осуществление которых необходимо получать предварительное согласие антимонопольного органа или Правительственной комиссии по контролю за осуществлением иностранных инвестиций в Российской Федерации (далее - Правительственная комиссия), предусмотрены статьями 27-29 Федерального закона от 26.07.2006 № 135-Ф3 «О защите конкуренции» (С3 РФ. 2006. № 31 (ч. 1). Ст. 3434) (далее - Закон № 135) и статьей 7 Федерального закона от 29.04.2008 № 57-Ф3 «О порядке осуществления иностранных инвестиций в хозяйственные общества, имеющие стратегическое значение для обеспечения обороны страны и безопасности государства» (далее - Закон № 57) (СЗ РФ. 2008. № 18. Ст. 1940).

При этом важно отметить, что Закон № 57 к сделкам применяется в случае, если приобретателем выступает 
иностранный инвестор (его группа лиц) в понимании указанного закона, а лицом, являющимся объектом экономической концентрации,- хозяйственное общество, имеющее стратегическое значение для обеспечения обороны страны и безопасности государства (далее - стратегическое хозяйственное общество) [7, C. 81-82].

В общем виде перечни сделок синхронизированы между собой, устанавливают необходимость получения предварительного согласия на приобретение акций, долей, имущества, прав в отношении хозяйствующих субъектов.

В этой связи, в случае приобретения иностранным инвестором акций (долей), имущества или прав в отношении российского хозяйственного общества при условии превышения пороговых значений в виде балансовой стоимости активов или выручки, на иностранного инвестора возложена обязанность по направлению ходатайств в антимонопольный орган: в соответствии с требованиями Закона № 135 и Закона № 57.

Каждый из указанных законов требует представления документов и сведений в отношении планируемой сделки и ее участников. При этом сами документы и порядок их представления отличаются.

Таким образом, представляется важным определить документы, имеющие значение для рассмотрения ходатайств в соответствии с нормами Закона № 135 и Закона № 57, и выявить пути совершенствования и синхронизации законодательства в этой части с целью повышения эффективности, качества и единообразия исполнения возложенных на антимонопольный орган функций.

Так, перечень документов и сведений, необходимых антимонопольному органу для рассмотрения антимонопольного ходатайства содержится в части 5 статьи 32 Закона № 135 (СЗ РФ. 2006. № 31 (ч. 1). Ст. 3434).

В свою очередь, перечень документов, необходимых для рассмотрения ходатайства в соответствии с Законом № 57, утвержден частью 2 статьи 8 Закона № 57 (С3 РФ. 2008. № 18. Ст. 1940).

Частично документы и сведения, предусмотренные указанными законами, соотносятся в части информации о заявителе (учредительные документы, сведения об акционерах (в том числе, о бенефициарах, выгодоприобретателях, контролирующих лицах), информации об основных видах деятельности, группы лиц), о лице, являющемся объектом экономической концентрации (учредительные документы, сведения об осуществле- нии им видов деятельности, предусмотренных статьей 6 Закона № 57), а также информации о сделке.

Указанная выше информация необходима для рассмотрения ходатайств в соответствии с Законом № 135 и Законом № 57, в ее отсутствие антимонопольный орган не может сделать вывод относительно влияния сделки на конкуренцию и наличия (отсутствия) необходимости согласования сделки с Правительственной комиссией.

Относительно иной информации необходимо отметить, что и Законом № 135, и Законом № 57 установлена обязанность по представлению ряда специальных для контроля за экономической концентрацией и контроля за иностранными инвестициями документов.

Так, в рамках антимонопольного контроля за экономической концентрацией необходимы документы о видах деятельности лица, являющегося объектом экономической концентрации, лицах, в которых он распоряжается более чем 5\% голосующих акций / долей, а также его группы лиц (СЗ РФ. 2006. № 31 (ч. 1). СТ. 3434).

Законом № 57 также предусмотрены отдельные документы, представления которых не требуется в соответствии с Законом № 135. К примеру, заявителю-иностранному инвестору необходимо представить проект бизнес-плана хозяйственного общества, имеющего стратегическое значение, в том числе с учетом вида или видов деятельности, указанных в статье 6 Закона № 57, по форме, утвержденной антимонопольным органом (СЗ РФ. 2008. № 18. Ст. 1940).

Вместе с тем имеющиеся расхождения в перечнях представляемых документов обусловлены различными целями осуществления контроля за экономической концентрацией и иностранными инвестициями. Кроме того, необходимо отметить, что обеспечение обороны страны и безопасности государства включает в себя, в том числе обеспечение экономической стабильности, соответственно, является более значимым направлением деятельности государства [1, с. 161].

К примеру, об этом свидетельствует пункт 3.1 части 2 статьи 33 Закона № 135, в соответствии с которым антимонопольный орган продлевает срок рассмотрения антимонопольного ходатайства до принятия решения по сделке Правительственной комиссией (СЗ РФ. 2006. № 31 (ч. 1). Ст. 3434).

Таким образом, рассмотрение антимонопольного ходатайства находится в зависимости от рассмотрения ходатайства в соответствии с Законом № 57, при этом комплексный анализ действующих законодательных актов не позволяет сделать вывод о наличии обратной зависимости [4, с. 719]. 
Указанные выше обстоятельства отражают лишь процесс рассмотрения ходатайства и не относятся к окончательным решениям по ходатайствам, поскольку принятие одним из уполномоченных органов решения об отказе в удовлетворении одного ходатайства автоматически означает невозможность осуществления сделки [2, с. 451-452].

Так, в случае поступления ходатайства ответственное лицо антимонопольного органа обязано проверить наличие в составе документов перечня лицензий лица, являющегося объектом экономической концентрации, на осуществление видов деятельности, предусмотренных статьей 6 Закона № 57 (См. напр.: Решение ФАС России от 04.08.2014 № АК/31250/14, Решение ФАС России от 24.07.2014 № АГ/29768/14, Решение ФАС России от 12.09.2014 № ЦА/36873/14 // URL: https://br.fas. gov.ru/ (дата обращения: 20.11.2021).

Соответственно, при рассмотрении антимонопольного ходатайства, помимо оценки влияния сделки на состояние конкуренции, антимонопольному органу также необходимо проверить наличие оснований для осуществления контроля за иностранными инвестициями, что свидетельствует о необходимости синхронизации положений Закона № 135 с Законом № 57 в части представляемых документов.

Особое внимание необходимо уделить основополагающим документам для анализа наличия (отсутствия) необходимости согласования сделки в соответствии с Законом № 57: сведениям о бенефициарных владельцах, выгодоприобретателях и контролирующих заявителя лицах, а также о лицензиях лица, являющегося объектом экономической концентрации, на осуществление видов деятельности, предусмотренных статьей 6 Закона № 57.

Относительно конечных бенефициаров, выгодоприобретателей и контролирующих лиц необходимо отметить, что с точки зрения контроля за экономической концентрацией необходимо провести анализ влияния сделки на состояние конкуренции. Проблема конечного бенефициара (выгодоприобретателя, контролирующего лица) возникает тогда, когда в рамках группы лиц не представлена информация о контролируемых таким лицом хозяйствующих субъектах, действующих на тех же или смежных товарных рынках. Такая информация важна для принятия решения и ее представление в составе ходатайства необходимо [3, с. 351].

Пункт 18 части 5 статьи 32 Закона № 135 предусматривает необходимость раскрытия информации о лицах, в интересах которых осуществляется владение более чем 5\% акций (долей) их номинальными держателями (СЗ РФ. 2006. № 31 (ч. 1). Ст. 3434).
Вместе с тем указанным законом не предусмотрен особый порядок предоставления указанной информации, не установлена необходимость указывать сведения о наличии или отсутствии гражданства иностранного государства или статуса налогового резидента.

В свою очередь, в рамках контроля за иностранными инвестициями раскрытие бенефициарных владельцев, выгодоприобретателей, контролирующих лиц является основным требованием [5, с. 63].

Правилами представления иностранными юридическими лицами, иностранными организациями, не являющимися юридическими лицами, и находящимися под их контролем организациями в федеральный орган исполнительной власти, уполномоченный на выполнение функций по контролю за осуществлением иностранных инвестиций в Российской Федерации, информации о своих выгодоприобретателях, бенефициарных владельцах и контролирующих лицах, утверждённых постановлением Правительства Российской Федерации от 01.12.2018 № 1456 «Об утверждении Правил представления иностранными юридическими лицами, иностранными организациями, не являющимися юридическими лицами, и находящимися под их контролем организациями в федеральный орган исполнительной власти, уполномоченный на выполнение функций по контролю за осуществлением иностранных инвестиций в Российской Федерации, информации о своих выгодоприобретателях, бенефициарных владельцах и контролирующих лицах» (далее - Правила) установлен широкий перечень информации, представляемой о физических и юридических лицах, являющихся иностранными инвесторами, включая информацию о гражданстве, статусе налогового резидента, а также реквизиты документов (СЗ РФ. 2018. № 50. Ст. 7768).

Как видно, объем и качество информации, представляемой в рамках контроля за иностранными инвестициями значительно превосходит соответствующие параметры, представляемые в соответствии с пунктом 18 части 5 статьи 32 Закона № 135, что, безусловно, влияет на рассмотрение антимонопольного ходатайства.

При этом существенные различия в объеме представляемой информации и ее качестве влияют на сроки рассмотрения ходатайства, в том числе в связи с необходимостью получения от заявителя дополнительной информации о бенефициарных владельцах, выгодоприобретателях и контролирующих лицах в порядке, установленном Правилами.

Таким образом, представляется необходимым синхронизировать положения Закона № 135 и Закона № 57 в части установления обязанности заявителя предо- 
ставления в рамках контроля за экономической концентрацией информации о бенефициарных владельцах, выгодоприобретателях и контролирующих лицах в соответствии с Правилами. Подобная синхронизация позволит избежать дополнительных запросов информации и, соответственно, повысит эффективность рассмотрения ходатайств.

Применительно к видам деятельности, подпадающим под действие статьи 6 Закона № 57, стоит отметить следующее.

Пунктом 19 части 5 статьи 32 Закона № 135 установлена обязанность по представлению в составе ходатайства перечня лицензий лица, являющегося объектом экономической концентрации, на осуществление видов деятельности, предусмотренных статьей 6 Закона № 57 ((СЗ РФ. 2006. № 31 (ч. 1). Ст. 3434)).

Вместе с тем лицензия не является единственным документом, позволяющим осуществлять стратегические виды деятельности.

К примеру, в силу пункта 45 статьи 6 Закона № 57 признается стратегической деятельность по аттестации сил обеспечения транспортной безопасности, осуществляемая аттестующими организациями в соответствии с законодательством Российской Федерации о транспортной безопасности (СЗ РФ. 2008. № 18. Ст. 1940).

Согласно части 8 статьи 12.1 Федерального закона от 09.02.2007 № 16-Ф3 «О транспортной безопасности» функции по проверке соответствия знаний, умений, навыков сил обеспечения транспортной безопасности, личностных (психофизиологических) качеств, уровня физической подготовки отдельных категорий сил обеспечения транспортной безопасности требованиям законодательства Российской Федерации о транспортной безопасности осуществляются органами аттестации, аттестующими организациями на основании договора, заключенного, В том числе с иной организацией (СЗ РФ. 2007. № 7. СТ. 837).

При этом для осуществления соответствующей деятельности юридическое лицо должно пройти аккредитацию в порядке, установленном приказом Минтранса России от 01.04.2015 № 145 «Об утверждении Порядка аккредитации юридических лиц в качестве подразделений транспортной безопасности и требований к ним» [6].

Таким образом, для осуществления вида деятельности, предусмотренного пунктом 45 статьи 6 Закона № 57, хозяйствующий субъект должен заключить договор в порядке, установленном иным нормативным правовым актом [5, с. 244].
Соответственно, наличие лицензии, как и ее отсутствие, не свидетельствует об отнесении хозяйственного общества к стратегическим. Указанные в статье 6 Закона № 57 виды деятельности могут осуществляться на основании разрешений, сертификатов и иных документов, предоставляющих такое право.

При этом отсутствие в Законе № 135 обязанности предоставления в составе ходатайства информации об иных документах, предоставляющих хозяйственному обществу право осуществлять стратегические виды деятельности, а также о фактическом осуществлении (неосуществлении) лицом, являющимся объектом экономической концентрации, данных видов деятельности, существенно увеличивает срок рассмотрения антимонопольного ходатайства. Кроме того, на практике возникают вопросы относительно полномочий антимонопольного органа по истребованию соответствующих документов при рассмотрении ходатайства в соответствии с требованиями Закона № 135, учитывая тот факт, что перечень документов, установленный частью 5 статьи 32 Закона о защите конкуренции, является исчерпывающим.

Дополнение части 5 статьи 32 Закона о защите конкуренции пунктами, в соответствии с которыми четко и исчерпывающе определялись документы, необходимые для проверки сделки (действия) на предмет необходимости согласования с Правительственной комиссией, существенно бы сократило сроки рассмотрения ходатайства, повысило осведомленность иностранных инвесторов о порядке и процедурах контроля за экономической концентрацией и иностранными инвестициями.

В свою очередь, дополнение перечня документов, представляемых в составе ходатайства в соответствии с Законом № 57, указанием на необходимость предоставления информации об основных показателях хозяйственной деятельности стратегического хозяйственного общества, позволит однозначно определить факт осуществления (неосуществления) таким хозяйственным обществом стратегических видов деятельности.

Отдельно также необходимо отметить, что обязанности представления информации о лицах, в которых лицо, являющееся объектом экономической концентрации, распоряжается более чем 5\% голосующих акций (долей), не корреспондирует обязанность предоставления информации об осуществлении (неосуществлении) такими лицами видов деятельности, предусмотренных статьей 6 Закона № 57 (СЗ РФ. 2006. № 31 (ч. 1). СТ. 3434).

На практике такая информация запрашивается антимонопольным органом в процессе рассмотрения хо- 
датайства с тем, чтобы однозначно установить наличие (отсутствие) необходимости согласования сделки в соответствии с Законом № 57, особенно в том случае, когда в рамках сделки приобретается большое количество хозяйствующих субъектов, входящих в одну группу лиц.

Соответственно, целесообразно дополнить Закон № 135 указанием на необходимость предоставления в составе ходатайства информации об осуществлении хозяйственными обществами, более чем 5\% голосующих акций (долей) которых лицо, являющееся объ- ектом экономической концентрации, распоряжается на любом основании, видов деятельности, предусмотренных статьей 6 Закона № 57.

Представляется, что внесение указанных выше изменений в перечень документов, представляемых одновременно с ходатайствами в соответствии с Законом № 135 и Законом № 57, позволит существенно повысить эффективность осуществления государственного контроля за экономической концентрацией и контроля за иностранными инвестициями.

\section{ЛИТЕРАТУРА}

1. Инвестиционное право: учебник / отв. ред. И.В. Ершова, А.Ю. Петраков. - Москва: Проспект, 2020-304 с.

2. Конкурентное право России: учебник / отв. ред. С.А. Пузыревский. - Москва: Проспект, 2021.—640 с.

3. Корпоративное право: Учебный курс. В 2 т. Т. 2: Учебно-методическое пособие / Шиткина И.С.— Москва: Статут, 2017.— 990 с.

4. Научно-практический комментарий к Федеральному закону «0 защите конкуренции» (постатейный) / К.Н. Алешин, И.Ю. Артемьев, Е.А. Большаков и др.; отв. ред. И.Ю. Артемьев. 2-е изд., перераб. и доп. М.: (татут, 2016. 1024 с.

5. Научно-практический комментарий к Федеральному закону от 29.04.2008 № 57-Ф3 «0 порядке осуществления иностранных инвестиций в хозяйственные общества, имеющие стратегическое значение для обеспечения обороны страны и безопасности государства» / Пред. редкол. А.Г. Цыганов; Федеральная антимонопольная служба. М.: Филиал Учебно-методического центра ФАС России, 2018. 424 с.

6. $0 б$ утверждении Порядка аккредитации юридических лиц в качестве подразделений транспортной безопасности и требований к ним: приказ Минтранса России от 01.04.2015. № 145 // Официальный интернет-портал правовой информации. — Москва, 10.07.2015.— URL: http://publication.pravo. gov.ru/Document/View/0001201507100023 (дата обращения: 17.11.2021).

7. Степанченко А.В. Иностранные инвестиции в стратегические отрасли экономики: некоторые проблемы применения Закона о стратегических иностранных инвестициях // Бизнес, Менеджмент и Право. 2013. № 1. С. 78-84. 